\title{
TOWARD A THEORETICAL FRAMEWORK OF RELATIONSHIP MARKETING IN THE BUSINESS CONTEXT
}

\section{TEORIJSKI OKVIR MARKETINGA ODNOSA I SURADNJE NA POSLOVNOM TRŽIŠTU}

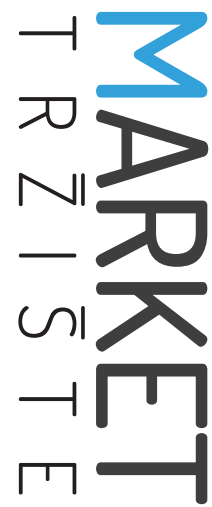

\author{
Market-Tržište \\ Vol. 31, No. 2, 2019, pp. 209-226 \\ UDK 658.8:005 \\ DOl http://dx.doi.org/10.22598/mt/2019.31.2.209 \\ Review
}

\section{Kawsar Ahmmed”, Shahidul Islamb ${ }^{b}$ Nor Azila Mohd. Noorc, Khandoker Mahmudur Rahman', Fizar Ahmede \\ a United International University, School of Business and Economics, United City, Madani Avenue, Badda, Dhaka 1212, BANGLADESH, e-mail: kawsar@bus.uiu.ac.bd \\ b University of Dhaka, Faculty of Business Studies, Dhaka 1000, BANGLADESH, e-mail: abmshahidul@yahoo.com \\ c University Utara Malaysia, Othman Yeop Abdullah Graduate School of Business, 06010, Sintok, Kedah-Darul Aman, MALAYSIA, e-mail: azila@uum.edu.my \\ d United International University, School of Business and Economics, United City, Madani Avenue, Badda, Dhaka 1212, BANGLADESH, e-mail: mahmud_edu@bus.uiu.ac.bd \\ e Daffodil International University, Dhaka 1207, BANGLADESH, e- mail: fizar.cse@diu.edu.bd}

\begin{abstract}
Purpose - This paper addresses the issues related to the practice of relationship marketing at the organizational level. Considering the influence of various factors, this study offers a theoretical framework necessary to create, maintain, and enhance the business relationship.
\end{abstract}

Design/methodology/approach - The research is based on a systematic review of existing literature, including journal articles, subject-specific professional websites, and textbooks on relationship marketing. Literature reviews relating to the Nordic School, Industrial Marketing and Purchasing (IMP) Group Approach, and the North American School are included.

Findings - The relationship marketing approach has evolved since the pre-industrial era, and more organizations are embracing this marketing stance in the current, post-industrial era. A theoretical framework that consists of influential variables for creating, maintaining, and enhancing relationships is proposed to explore this multidimensional construct. Information on proper con-

\section{Sažetak}

Svrha - U radu se istražuju problemi vezani uz praksu marketinga odnosa i suradnje na organizacijskoj razini. Uzimajući u obzir utjecaj različitih faktora, rad nudi teorijski okvir za stvaranje, održavanje i unapređenje poslovnog odnosa.

Metodološki pristup - Istraživanje se temelji na sustavnom pregledu postojeće literature uključujući znanstvene članke iz časopisa, tematski vezane profesionalne web stranice i udžbenike o marketingu odnosa i suradnje. U pregled literature uključeni su pristupi istraživačkih inicijativa Nordic School, Industrial Marketing and Purchasing (IMP) Group te North American School.

Rezultati i implikacije - Marketing odnosa i suradnje razvija se od predindustrijskog do poslijeindustrijskog vremena, a sve više organizacija prihvaća ovaj pristup. Za ovaj je multidimenzionalni konstrukt predložen teorijski okvir koji se sastoji od utjecajnih varijabli za stvaranje, održavanje i poboljšanje odnosa. Sintetiziraju se informacije o odgovarajućim uvjetima koje bi marketinš- 
ditions is synthesized to help marketers identify an appropriate environment for implementing this approach in the business context.

Limitations - Given the increasing complexity of relationship marketing and the increasing need to understand this approach, the proposed theoretical framework could be useful for improving the understanding of multi-dimensional aspects of relationship marketing. Consequently, directions for future research in relationship marketing are identified.

Originality/value - This study provides a coherent picture of relationship marketing viewed through the proposed theoretical framework, based on a systematic literature review. Specifically, it is probably a first instance in which a paper sought to address the practice of relationship marketing by including tripartite areas - namely, creating, maintaining, and enhancing relationships in a Business to Business (B2B) setting, which is scattered across various disciplines.

Keywords - relationship marketing, communication, trust, commitment, duration of the relationship kim stručnjacima pomogle u pronalasku odgovarajućega okruženja za provedbu ovoga pristupa u kontekstu poslovnog tržišta.

Ograničenja - S obzirom na sve veću složenost marketinga odnosa i suradnje vis-à-vis sve veće potrebe za razumijevanjem pristupa, predloženi bi teorijski okvir bio koristan za bolje razumijevanje multidimenzionalnih aspekata marketinga odnosa i suradnje. Slijedom toga, utvrđeni su pravci za buduća istraživanja u marketingu odnosa i suradnje.

Doprinos - Rad pruža koherentnu sliku marketinga odnosa i suradnje promatranoga kroz predloženi teorijski okvir, temeljen na sustavnom pregledu literature. Konkretno, ovo je vjerojatno prvi put da se rad pokušao baviti praksom marketinga odnosa i suradnje uključivanjem tripartitnog područja - stvaranjem, održavanjem i poboljšanjem odnosa u poslovnom (B2B) području koje je raspršeno po različitim disciplinama.

Ključne riječi - marketing odnosa i suradnje, komunikacija, povjerenje, predanost, trajanje odnosa 


\section{INTRODUCTION AND BACKGROUND}

The present paper discusses the practice of relationship marketing and tries to explore different issues related to relationship marketing using a comprehensive domain review. The building, maintaining, and enhancing of a marketing relationship with the customer is pivotal for any marketer as it impacts positively on the organization's economic performance, customer satisfaction, and retention, as well as on joint value creation, competition, images, etc. As customers are very much empowered today, selling to them requires a focused strategic approach. Relationship marketing concentrates on this area and seeks to show that effective management of relationships leads to marketing success (Godson, 2010). Additionally, it focuses marketing efforts and resources on developing and maintaining long-term close relationships with linear and constellation ways. As one of the pioneers in the field of relationship marketing, Berry (1983) describes relationship marketing as "attracting, maintaining and-in multi-service organizations-enhancing customer relationships."

Grönroos (1990) states that relationship marketing is to "identify and establish, maintain and enhance relationships with customers and other stakeholders, at a profit, so that the objectives of all parties involved are met." Mattsson (1995) considers exchange to be central to the marketing concept, and within the exchange relationship, "specific individual dependency" is available between the parties. Relationship marketing involves and integrates customers, suppliers, and other related parties in a value delivery network through mutual reliance and collaboration over time.

Marketers are not only interpreting the existing customer needs on the basis of their buying behavior; rather, they must predict future customer requirements to satisfy these needs and ensure customers' brand loyalty. To predict customer future requirements properly and re- spond accordingly, a close long-term relationship is necessary. Patterson (1995) explains that, through an ongoing commitment and communication, a company can meet expectations and deliver on what it promises to create positive attitudes and behavior within customers' minds, as this is central to most successful relationship marketing efforts. Although the nature and role of marketing relationships are discussed in different settings and industries, the nature of such relationships depends on the environment where the interaction happens (Hallen \& Sandstorm, 1991). Studies have identified several forces, including rapid technological advancement, adoption of total quality programs, the growth of the service industry, empowerment, and competitive intensity as necessary for the development and practice of this relational approach (Seth \& Parvatiyar, 1995).

In the field of marketing, scholarly research on relationship marketing is abundant. But in view of the factors that influence the creation, maintaining and enhancing the business relationship, that research is patchy. Relating to three research directions, namely concept level, model level, and process research (Wilson, 1995), this study is an attempt to provide a process to initiate, maintain, and enhance relationship. As the conceptual foundations of relationship marketing are not currently well developed (Sheth, Parvatiyar \& Sinha, 2015), the processes through which relationships are established, developed, and maintained (Eiriz \& Wilson, 2006; Keegan, Rowley \& Tonge, 2017) are proposed in this study.

To this end, studies such as those examining customer knowledge competence to manage relationship management programs (Campbell, 2003), a process-based conceptual framework (Payne \& Frow, 2005), retention program for customer satisfaction (Winer, 2001), customer value dimension, and CRM performance (Wang, Po Lo, Chi \& Yang, 2004) provide us with partial ideas on how to maintain a customer relationship. Besides, the roles of trust, commitment, and satisfaction in a marketing relationship 
(Garbarino \& Johnson, 1999; Morgan \& Hunt, 1994), and the relationship profitability model (Storbacka, Strandvik \& Grönroos, 1994) have been explored in a bid to make the relationship a profitable one. Arguably, these studies are rather divergent and do not provide a clear and consistent picture.

Furthermore, the influence of both macro- and microenvironmental elements on creating, maintaining, and enhancing business relationships is not addressed properly in the existing literature. This scarcity appears to mandate the development of a relationship marketing framework through a domain review that would identify the key dimensions of creating, maintaining, and enhancing business relationships.

This research is based on a systematic review of existing literature on relationship marketing. This review includes journal articles, subject-specific professional websites, and relationship marketing textbooks. In addition to the term relationship marketing, other suitable synonyms are also used to get the relevant resources. Literature relating to the Nordic and Anglo-Australian School on service, the IMP Group Approach to interactive relationships, and the North American School on dyadic relationships (Palmer, Lindgreen \& Vanhamme, 2005) that covers past and recent studies is included. All the information available in the paper is obtained by maintaining strict ethical standards and reported accurately with proper referencing. Literature review traces the practices of relationship marketing in different ages, including the pre-industrial, industrial and post-industrial age, and identifies the ways to create, maintain, and enhance relationships. Besides, microelements as well as conditions for the practice of relationship marketing are also identified. Based on the identified variables, researchers have developed a theoretical model for creating, maintaining, and enhancing marketing relationships.

The remaining parts of this paper are organized as follows: first, a brief history of relationship marketing is given before we turn to developing a framework to describe how to create, maintain, and enhance the relationship. As microelements have a profound impact on the practice of relationship marketing, we discuss it in the subsequent section, followed by the suitability of practicing this approach. The paper concludes with several implications and conclusions.

\section{A BRIEF HISTORY OF RELATIONSHIP MARKETING: SKETCH FROM THE LITERATURE}

Relationship marketing has a long tradition which began in the pre-industrial era. Although the scope and nature of such business relationships were different in the primitive age, literature shows that it was practiced for the betterment of parties to the exchange. Relationship marketing can be termed as the rebirth of the marketing practices during the pre-industrial age or simple trade age (Khalil \& Harcar, 1999; Sheth, 2011; Sheth \& Parvatiyar, 1995) by which business parties worked together and built structural and emotional relationships in their transactions.

Figure 1 below shows the wave of relationship during the primitive, industrial revolution, and modern age.

During this time, service personalization or customization was the key due to one-to-one relationships. More detailed discussions on different eras of relationship marketing are provided below. 
FIGURE 1: Evolution of relationship marketing

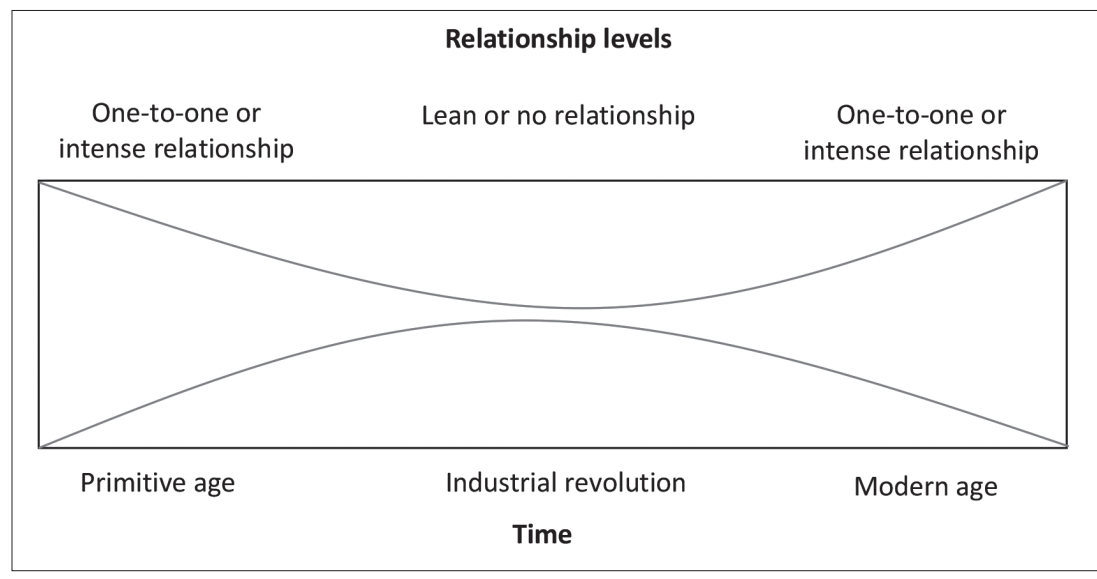

\subsection{Pre-industrial business relationships}

The pre-industrial era, mainly before 1780, was the era of no machine manufacturing, and mechanization and life were without gadgets, shopping mall, microwaves, manufactured automobiles, or the Internet. Family members were producing the items they needed in their houses, a so-called cottage industry, at the subsistence level. Unlike today, some people did offer their services and goods for sale within their clan, neighbor, and rural community. As merchants these people had the roles of was both the "producer" and "seller" of their merchandise. Communication among the parties in business was limited to the communities and elements of trust acted as glue in these clan-based trade relationships, where outside parties could hardly take part in the system (Mwamula-Lubandi, 1992). Literature shows that these relationships continued for a long time as the parties trusted each other's clans and family (Kingson, Hirshorn \& Cornman, 1986).

Since transactions were completed among selected clans or tribes in a consistent manner, familiarity and face-to-face interaction among the business parties helped them to customize the offerings (Sheth \& Parvatiyar, 1995). The existence of great heterogeneity of enterprise forms in the preindustrial society played a vital role (Gelderblom \& Trivellato, 2018) in meeting the diversities.

To this end, strong efforts of Chinese silk manufacturers to create a market and promote continuing business activities alongside the "silk trade route" (Feltwell, 1991; Li, 1981) are notable. Business relationships between the parties involved in silk trade were essential since Indian silk craftsmen were extremely dependent on the Chinese silk to produce clothes and artifacts for the local kings and nobles; subsequently, this rapport developed mutual dependencies between the suppliers of silk and garment producers (Sheth \& Parvatiyar, 1995). During that time, family names were used to identify the product, to ascertain a certain warranty of quality, to give consumer satisfaction, to stimulate re-purchase, and to expedite future transactions (Crone, 1989).

\subsection{Relationship marketing in the industrial era}

The industrial era was characterized by mass production and mass consumption (Kotler, Armstrong, Agnihotri \& Haque, 2010). Due to this opportunity, manufacturers enjoyed the economies of scale advantage that helped them to reduce the cost of products and thus also the market price of the products they offered. This reality increased the level of inventory of finished products and pressing demand 


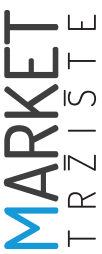

to create new markets. Accordingly, aggressive selling efforts and the growth of marketing organizations, including different marketing intermediaries, emerged. These intermediaries bore both the risks and costs of inventory storage and ownership. Mass production and mass consumption created job opportunities for a number of people who started moving from their own-managed small sustenance farms to jobs in industrial cities, generating an environment for retail organizations to supply the required items in the right form that may meet the basic necessities (Cundiff, 1988).

Since business orientation was largely transactional during the industrial era, marketing performance was measured by sales revenues and profitability. As competition increased with additional capability, the orientation of maximizing profit in the short run dominated marketing practices. Gradually, marketers realized the benefits of target marketing for which they could customize their marketing offerings and programs, thus effectively differentiating themselves from those of their competitors (Peterson, 1962). The development of AVMS or Administered Vertical Marketing Systems (McCammon, 1965), such as franchising and exclusive distribution systems, is another variation that provided the opportunities for them to extend their presence beyond their corporate limits and reach the end-users (Little, 1970). Numerous industrial buyers and sellers embarked on longer-term agreements with each other for constant deliveries and services to avoid uncertainty, creating an on-going interactive relationship between themselves like that of McDonalds with Coca-Cola that has been in place for more than 50 years (Hakansson, 1982).

\subsection{Relationship marketing in the post-industrial era}

In the post-industrial era, marketers' understanding of customer interest and their concern for customers supplemented the transaction-oriented approach with a relational orientation. In the field of managerial thinking and practice, substantial development has been made toward the adoption of relationship marketing based on perennial interactions between the parties involved.

The growth and practice of relational orientation during the post-industrial era is the renaissance of direct marketing in new shapes and dimensions which were available in the pre-industrial age. Several micro and macro factors emerged from the environment, and organizations are responsible for this relationship-oriented marketing between producers and consumers.

Sheth and Parvatiyar (1995) identified five macroenvironmental forces for growth of the relational orientation in marketing. A rapid technological advancement, implementation of total quality programs by the companies, along with the development of the service industry, empowerment of individuals and teams through the organizational development process, and an increase in competitive intensity lead to a concern for customer retention by the organizations.

\section{PRACTICE OF THE RELATIONSHIP MARKETING APPROACH}

Relationship marketing cannot be considered an isolated issue by separating all the influencing forces relating to it. Rather, it is a complex combination of various factors within the overall socio-cultural environment, which in turn consists of and is influenced by many sub-factors that specify the systematic and logical relationship among the micro- and individual variables (see Figure 2). In the business arena, relationship marketing is the outcome of some subsystems that create integration among the activities and efforts of relevant individuals, claimants, and stakeholders. The relationship among the elements at the beginning is spontaneous and later on imposed. For example, creating a business relationship is a subsystem in the integrated system of relationship marketing, the smooth 
functioning of which is influenced by several constraining factors like relationship benefits, symmetry, two-way communication, reciprocity, and others. Pre-defined and contingent rules, regulations, and guidelines govern the smooth functioning of the specific factors for creating a relationship with the business parties. After a certain time, this process gains the ability to survive, operate, and excel in its respective field due to its innate strengths. However, as the expectations of relevant stakeholders are dynamic and the environment has the inherent features of changes, flexibility and innovations must be incorporated into the system to ensure its longterm survival. At the same time, the subsystems available in the relationship marketing framework should work together with continuous coordination.

Beyond the included variables of the present study, the relationship context is influenced by many other factors, including gratitude or feelings of gratitude (Raggio, Walz, Godbole \& Garretson Folse, 2014; Mishra, 2016; Palmatier, Jarvis, Bechkoff \& Kardes, 2009), context (Sheth, 2011), larger relationship marketing efforts (i.e. relationship-specific investments) towards a company's key customers (Brettel, Strese \& Flatten 2012), conflict, and cultural (Keegan et al., 2017) factors. Many of them have similarities to the existing variables: some upper order variables are selected, and lower order variables are ignored. For example, in case of creating a business relationship, the feeling of gratitude is ignored and reciprocity is included because the relationship can generate a more fruitful result in the presence of reciprocity rather than mere gratitude.

The practice of relationship marketing follows a dynamic process that requires a continuous adjustment in the changing perspective to redefine the level of relationship marketing and redesign the process of creating, maintaining, and enhancing the relationship. Although the complex relationship is prevalent among the variables (Brown, Crosno \& Tong, 2019; Mysen, Svensson \& Payan, 2011), we are describing them in terms of general variables. Therefore, some interrelationship between the variables cannot be ruled-out.

FIGURE 2: Practice of relationship marketing

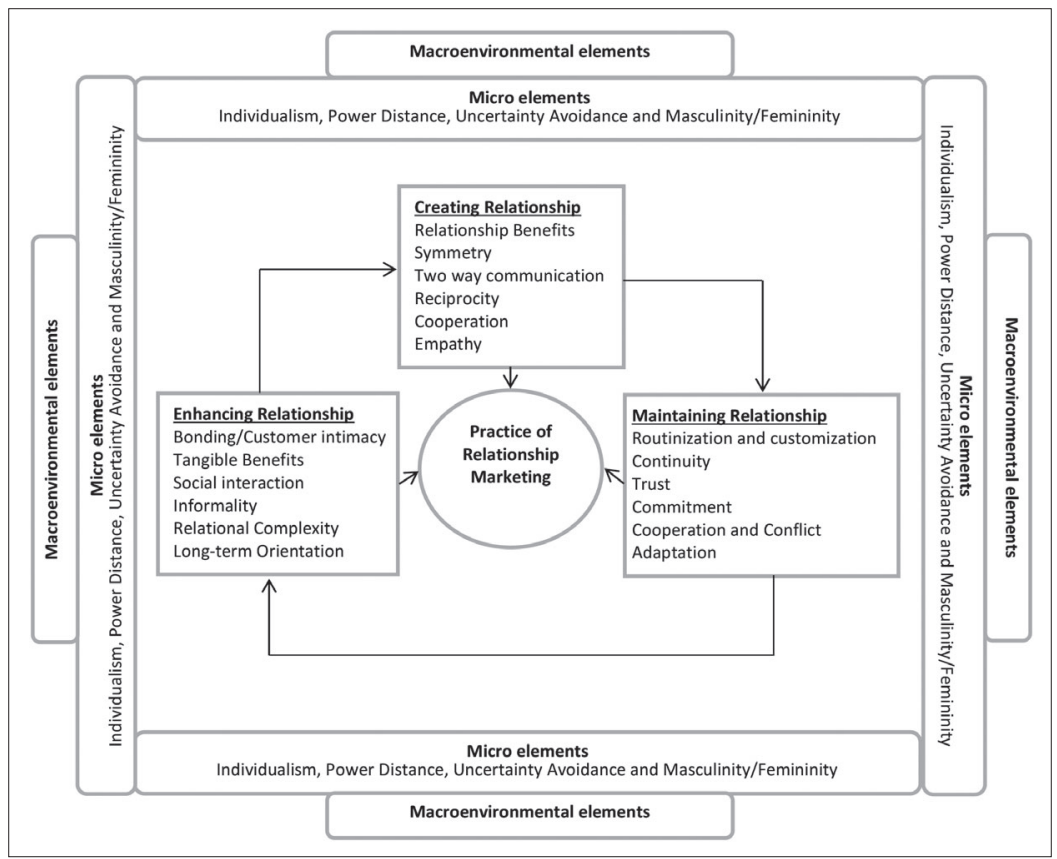




\subsection{Creating a relationship}

Relationship marketing has become an integral and necessary part of business practices that require a dedicated amount of time and energy to build. The following factors show the ways to build a suitable relationship with the business partners.

\section{a) Relationship benefits}

People like to engage in a relationship with the aspiration that such relationship will generate benefits for them. Walter, Ritter and Gemünden (2001) claim that relationship marketing generates both financial and nonfinancial benefits for the business parties. This is because the practice of relationship marketing creates greater values for its customers than those provided by the core product itself (Grönroos, 1995). Such superior values influence customer satisfaction and gradually generate customer loyalty. Although questions about whether the claimed benefits are enjoyed by the parties involved in the relationship have been raised (Fournier, Dobscha \& Mick, 1998), most studies and practices assume that effective relationship marketing enhances performance outcomes, including sales growth, market share, and profits, a positive rapport, competitive advantage, information on fast-moving and best-selling items, as well as information on competition, their activities, and most attractive prices (Crosby, Evans \& Cowles, 1990; Ganesan, 1994; Hwang, Seo \& Choi, 2013; Morgan \& Hunt, 1994). The comprehension of such benefits can accelerate the relationship among the involved business parties.

\section{b) Symmetry}

A business relationship should be built on symmetry in terms of resources (human, knowledge, financial, technological) and initiative of the related parties. Typically, in the end-user markets, parties are balanced in their business relationship with regard to resources and capabilities. In contrast, the scenario is different where buyers may possess superior resources and capabilities to those of the suppliers in industrial markets (Håkansson \& Snehota, 1995). Partners' symmetry in terms of resources helps parties in setting shared goals and values and avoiding the attainment of competitive goals, which in turn impact positively on the creation of the relationship.

\section{c) Two-way communication}

A marketing relationship cannot exist and continue for long unless there is two-way communication providing for mutual interaction. This is so because two-way communication ensures the sharing of mutual information that develops knowledge and understanding about the parties' expectations and also helps in developing an exact response from the parties involved. Kelley and Thibaut (1978) note that, through information sharing, parties in the exchange process come to achieve better outcomes of their mutual behaviors. Hart (1996) posits that two-way interaction reduces the customers' switching tendency as they have invested a lot to make their marketers know about their needs and, if they wish to switch to a new supplier, they have to start a new run.

\section{d) Reciprocity}

The notion of reciprocity implies that partners may feel an obligation to respond positively to certain actions by another partner irrespective of the existing power imbalance. A business relationship thrives when each party gives of themselves to others. In their study, Chris and Graham (2007) claim that in each long-standing business relationship some form of give-and-take takes place, and one party makes some allowances for another party and expects to get the same treatment from its counterpart when its needs arise. This reciprocity generates indebtedness among the parties to build up their business relationship.

\section{e) Cooperation}

Cooperation is a process by which individuals, groups, and organizations come together, in- 
teract, and form psychological relationships for mutual gain (Smith, Carroll \& Ashford, 1995). The buyer-seller relationship is a complex phenomenon where companies with various domains, size, and culture are linked with each other. Due to these differences, functional interdependency is inevitable as parties specialize in performing certain tasks (Robicheaux \& El-Ansary, 1976). The latter authors explain that this task interdependency may bring about a channel conflict, and the achievement of a channel member's goals requires a certain level of cooperation. Therefore, cooperation acts as glue between a buyer and a seller as they build up their relationship.

\section{f) Empathy}

Because of individual characteristics and culture, we are different from each other in showing our needs. This diversity is expressed through the heterogeneous requirements we make at the time of meeting those needs. To this end, caring for customers as individuals in the form of empathy is necessary. Chris and Graham (2007) posit that the ability of the organization to see situations from the perspective of the other party ensures an emotional link in the development of relationships.

\subsection{Maintaining a relationship}

A marketing relationship takes the investment of time and effort to build and maintain even if it does not benefit the parties immediately. Each business partner needs to treat the relationship as a garden that requires the nurturing and should be aware of it at all times. Organizations that make efforts to maintain a successful business relationship are rewarded with a good return. Following are the ways to maintain a relationship in the marketing arena.

\section{a) Routinization and customization}

Over time, business relationships tend to become institutionalized although they are often complex and informal. Routine acts as a mechanism that facilitates customers and suppliers to tighten their relationship, enable a routinized exchange of valued information, and resolve possible conflicts. Routines help in coping with the complex requirements and coordinating individual activities in the relationship while also playing a key role at the organizational level where routines have been adopted (Nelson \& Winter, 1982). Like routinization, caring for customers as individuals is crucial for the marketer to maintain a win-win relationship. Technological sophistication has made customization easier through the use of various gadgets and media such as smartphones, electronic mail, social media, and the Internet for order receiving or complaints tracking and handling. From the FedEx and UPS web pages, customer can easily customize their information requirements to track their package and, accordingly, such facilities meet the customer's specific information requirements (Hoffman \& Novak, 1996).

\section{b) Continuity}

Continuity is a major feature in maintaining the buyer-seller relationship. Major supplier and customer relationships often show a high level of continuity and steadiness with different stages of making contacts, delivering goods and services as well as in post-delivery support and services. Various studies showed 10 to 20 years as a typical age of the relationships that the company maintains with its main business counterparts (Hallen, 1986). Relationship duration acts as an essential criterion for the wide-ranging use of the relationship by the parties involved, and continuity forces adjustments to or a new development of such relationships (Håkansson, 1989).

\section{c) Trust}

Trust is a firm's belief that another party will behave in such a way to generate positive consequences and will not engage in any undesirable activity that may generate negative results for the firm (Anderson \& Narus, 1990). Trust is ultimately the glue that holds a relationship to- 
gether over the long haul. A study by Chris and Graham (2007) found that a high level of trust results in more cooperation and coordination between the relationship partners and has a key role in the collaborative buyer-vendor relationship (Hwang \& Suh, 2017).

\section{d) Commitment}

Commitment is a sense of intention that indicates the parties' seriousness towards a particular relationship to continue over time. Dwyer, Schurr and Oh (1987) relate commitment to the willingness to make short-term sacrifices in order to achieve long-term benefits from the relationship. Thanks to commitment, parties in a relationship can work together to meet their requirements better and ensure the success of their relationship through mutual gains. Having researched it, Moorman, Zaltman and Deshpande (1992) say that commitment is enduring; it denotes the willingness to carry on the existing relationship for long and enjoy the benefits of such a lengthy relationship (Wilson, 1995). Gundlach, Achrol and Mentzer (1995) explored commitment as an essential ingredient of successful long-term relationships.

\section{e) Cooperation and conflict}

Cooperation and conflict are intertwined with each other in a relationship. Naturally, exchange parties try to maximize their interests from the exchange relationship. When they consider that their goals are competitive rather than cooperative, then they act opportunistically. At this point, competition is available rather than cooperation; barriers are created rather than support of each other in the pursuit mutual goals. It is also true that a business relationship does not guarantee the resolution of all conflicts, bit the availability of some amount of conflict may produce a positive impact to keep the relationship healthier. In the value delivery network, functional interdependency may bring conflict and the achievement of mutual goals requires a certain level of cooperation (Robicheaux \& El-An- sary, 1976). Therefore, cooperation and conflict seem like two sides of the same coin that help in maintaining the health of a marketing relationship.

\section{f) Adaptation}

Because of various macro- and microenvironmental forces, business environment is always changing. In such a dynamic business environment, it is necessary to adjust to the changes. Through adaptation marketers can adopt new behaviors that allow them to cope with the changes. Adaptive activities may be anticipatory, i.e. before any impact is observed, and reactive, i.e. after the impacts have been felt. In the business relationship, some kind of mutual adaptation acts as a prerequisite for developing and maintain a relationship between two parties (Hallen, Johanson \& Seyed, 1989). As such, continuous modification and adaption to the changes help keep the relationship going for long.

\subsection{Enhancing relationship}

Building and maintaining a good relationship with the clients is not only the smart move to make from a marketing standpoint but is necessary in order to anticipate the clients' needs and make the continuous adjustment so that marketers can improve business over time. This can push the relationship to a collaborative, win-win partnership. Practicing the following strategies can increase the marketers' capability to enhance their relationship with the customers.

\section{a) Bonding/Customer intimacy}

Bonds create the exit barriers that tie the customer to the firm and maintain the relationship for a long time (Wendelin, 2011). As a bond becomes stronger with the passing of time, it ensures and increases each party's commitment to maintaining a relationship than is the case of partners without strong social bonds (Jobber \& Fahy, 2006; Wilson \& Mummalaneni, 1986). Strong bonds produce rewarding results that 
maintain relationships and keep them operational through hard times (Pillai \& Sharma, 2003). Closeness determines the longevity of the relationship between the parties involved. Morgan and Hunt (1994) identify the relationship that goes beyond strict economic boundaries as a key characteristic of a lengthy relationship. As the relationship evolves, customers and employees in organizations feel a sense of association towards each other that fosters customer proximity and, in turn, helps enhance the existing relationship.

\section{b) Tangible benefits}

Although tangibles include the physical evidence that provides an excellent opportunity for the marketer to share consistent and strong messages with the customers, here tangibles are used to delineate the benefits that can be measured in hard numbers and that help improve an existing relationship. Customers rely on tangible benefits while they consider maintaining and enhancing the existing relationship. Improved communication, an increase in revenue and overall business results, increased service and product quality, improved flexibility and stability, increased internal efficiency, reduced operating costs, and an increase in customer satisfaction all impact positively and enhance the existing relationship with one's clients.

\section{c) Social interaction}

As human beings, we have both a rational and emotional existence where no machine-like relationships exist. Parties involved in the marketing relationship have the tendency to texture a web of individual affiliation, and these personal bonds and convictions have profound influence on the enhancement of inter-organizational relationships. Social interaction develops social bonds, and trust appears as one of the significant elements influencing the continuous dealings in inter-company relationships (Dwyer et al., 1987).

\section{d) Informality}

Although formal contracts are very common, in most cases their role is often limited (Macaulay, 1963). A formal relationship follows boundaries, which are sometimes less effective in dealing with the uncertainties, conflicts, and crises that may occur at any stage of a marketing relationship. Several studies found that informal mechanisms are more effective in the development of a business relationship than formal engagements. Korneliussen (2011) explored the non-marketing relationships to improve, maintain, and strengthen ongoing marketing relationships with foreign actors.

\section{e) Relational complexity}

One of the fundamental challenges for enhancing the business relationship is the efficient management of relational complexity. The complexity of business networks includes the social and economic structures of actors and the dynamic processes of interactions and transactions between these actors (Todeva, 2005). Both the expectations and the results from the relationship are multiple and the relationship is used to achieve these diversified goals. Besides, established and a well-functioning relationship can be utilized for different purposes in different situations (Håkansson \& Snehota, 1995). Due to the relational complexity, the goals set by the parties may be misaligned, which results in adversarial relationships, lack of transparency and trust, a culture of blame (Baiden, Price \& Dainty, 2006), and may ultimately lead to a termination of the relationship. Therefore, effective handling of relational complexity is intertwined with the enhancement of existing marketing relationships.

\section{f) Long-term orientation}

Continuity is a major feature of relationship marketing where business activities happen repeatedly between two companies for years. The length of a relationship acts as a prerequisite for the extensive use of that relationship

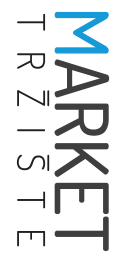




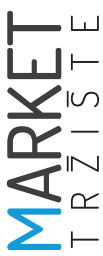

by the parties involved, and its very continuity brings about a change or a new development of such relationships (Håkansson, 1989). An extended relationship is positively related to customer retention (Bolton, 1998), repurchase intentions, and positive behavior (Seiders, Voss, Grewal \& Godfrey, 2005). Business parties with a long-term orientation focus on attaining future goals and are concerned with both present and future outcomes (Ganesan, 1994). Gill, Swann Jr. and Silvera (1998) explained that people in long-term relationships have considerable confidence in the assessments of their partners, regardless of whether those beliefs are accurate; long-term relationships are therefore included in this study (Wang, Shi \& Barnes, 2015).

\section{MICRO-ELEMENTS AND A BUYER-SELLER RELATIONSHIP}

As a micro-element, culture has a great impact on the creation, maintainance, and enhancement of the marketing relationship. It is the conventional behavior of a society which is common and approved by that society, and also transmitted from one generation to the next through learning. Persons' wants and behavior are directly influenced by the culture that varies from country to country (Kotler et al., 2010). As a generic theory (Clark, 1990), national culture is used in marketing research to describe the differences in decision-making in the field of marketing management (Tse, Lee, Vertinsky \& Wehrung, 1988) as well as market orientation (Dash, Bruning \& Guin, 2007). The following discussion shows the four dimensions of a national culture - namely, individualism, power distance, uncertainty Avoidance, and masculinity/femininity (Hofstede, 1980) - which influence the business relationship.

\subsection{Individualism}

An individual or collective perspective influences the interpersonal relationship and different achievements. Dash and others (2007) explain that a society with less individualism shows a more collectivist nature and reinforces extended families thinking about and believing in collective achievement. Therefore, a society characterized by individualism represents a looser relationship in the business arena.

\subsection{Power distance}

Hofstede (1983) outlined that inequality is prevalent in society, and the degree of this inequality differs from one society to another. In the high power distance society, an asymmetrical relationship such as parent-children, teacher-student, and superior-subordinate exists; this type of relationship is less stable, it ignores the power balance and motivates a powerful party to capitalize on its interests at the expense of a weaker party during difficult economic situations (Pedron \& Saccol, 2009). On the other hand, a symmetrical relationship is more stable because in such a relationship parties have an equal mutual dependency on each other (Britton \& Rose, 2004).

\subsection{Uncertainty avoidance}

In an established relationship, the time dimension referring to future uncertainties is involved as the relationship evolves. In the social context, a country ranked high on uncertainty avoidance has less tolerance for ambiguity and uncertainty (Dash et al., 2007), so the resultant outcome is a loose association. On the other hand, a country with low uncertainty avoidance is less concerned about ambiguity and uncertainty and more open to considering a variety of opinions (Dash et al., 2007), so the probability of a close relationship is higher.

\subsection{Masculinity/Femininity}

"Doing and acquiring rather than thinking and observing" is the main view of masculine cultures (Newman \& Nollen, 1996). In contrast, nurturing is the main feature of feminine cultures. Perceived cost and benefits of an activity are two bases to sustain the relationship in the masculine culture (Dash et al., 2007). On the other hand, in feminine societies business partners 
love to maintain greater harmony (Dash et al., 2007) and show a high level of tendency to develop commitment by considering positive or goodwill factors that ultimately generate effective commitment (Geyskens, Steenkamp, Scheer \& Kumar, 1996).

\section{IS RELATIONSHIP MARKETING FOR ALL?}

It is evident from the industrial marketing model that customer focus is the primary goal of all relationship marketing. Here companies assess and select those customers with their present and future profitability, and that profitability is measured in an integrated manner through calculating costs of products and services, delivering costs required to attract, sell, serve, and retain customers (Krznaric \& Popovski, 2001). Although relationship marketing generates both financial and nonfinancial benefits for the parties involved (Walter et al., 2001), recent studies suggest that more value is created through the transactional exchange than through relational exchange (Adrian, 1996) because of an asymmetric association with imbalances in knowledge, power, and resources instead of mutual trust and compassion (Barnes, 1994).

According to Adrian (1996), the relational exchange may not make sense if the following circumstances prevail in a particular business environment:

o if a buyer does not have to return to a seller and maintain relationships;

o if an asymmetric relationship is available where buyers are less powerful than the sellers;

o if the buying process is formalized where developing relationships is worthless;

0 if existing laws protect the buyer interest and make buyers confident what may be the outcome of the business relationship;

$\mathrm{O}$ in the price-sensitive market, if relationship development costs are higher which may generate a cost disadvantage situation for a firm; and lastly,

0 if the business relationship motivates anti-competitive practices and such practices reduce the buying choices.

Thus, allocating the right capacity at the right time at the right price to maximize revenue generation is essential for modern marketers. In this regard, inappropriate adoption of this relationship approach is challenging, as Payne and Frow (2005) say that:

o $\quad 69 \%$ of customer relationship management projects fail to generate greater impact on sales performance;

o companies believe their consultants or suppliers are more effective in generating positive results than their customer relationship management projects;

o $\quad 70 \%$ of customer relationship management projects will not work or stop within the next 18 months;

- $60 \%$ percent of customer relationship management initiatives end without fruit.

\section{IMPLICATIONS OF THE STUDY}

Based on the review of the relationship marketing domain, the present paper highlighted several implications. As our existing knowledge needs to be expanded, a proper understanding can be attained from the preliminary parts of this article. The introductory and evolution part provide us with useful information to understand its nature, evolution of the approach from the ancient era to the modern age. Graphic representation of the evolution of relationship marketing adds the differential values through which we can visualize the momentum of relationship practices in different ages.

At the organizational level, marketers must know how to develop, maintain, and enhance the valued relationship with business partners.

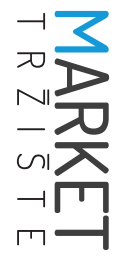


Figure 2 provides guidelines on how to create, maintain, and enhance the relationship. The isolation of various factors and subfactors make the marketers knowledgeable and supports their practice of relationship marketing which, in turn, helps them to ensure expected outcomes. Also, taking micro-level and macro-level elements into consideration, marketers can become vigilant and improve their capability so that they can survive, respond, grow, and sustain the business relationship in the ever-changing business environment.

Because relationship benefits make sense, practicing the approach at the organizational level to reap the best results from this process, knowledge about various conditions in which it operates effectively is pivotal. From the aspect of necessary conditions for a relationship, readers can accumulate knowledge about these conditions that will help them implement the process properly.

Since a person's wants and behavior are directly influenced by a culture that varies from country to country (Kotler et al., 2010), so does any approach practiced at the organizational level. In different nations, as variations are available on micro environmental aspects, practitioners must take into consideration the national culture before going ahead with the relational marketing approach.

Finally, adoption of the relationship marketing approach requires the fit of organization, customer, and the strategic choices of the upper echelon. Thus, proper knowledge can aid the decision-maker to execute this approach at the organizational level. The discussion under the topic "is relationship marketing for all" helps readers to realize how to avoid the unrealistic pursuit of the relationship marketing stance at their organizational level.

\section{CONCLUSION}

With its long tradition, the modern state of relationship marketing is considered as the rebirth of relationship practices of the pre-industrial era or simple trade era. Keeping this in mind, this research study attempted to trace the issue relating to the development of a theoretical framework for creating, maintaining and enhancing business relationships. As customers are very much empowered today, selling to them requires a focused strategic approach which relationship marketing aims to fulfill. To build, maintain, and enhance a marketing relationship, the organization should put emphasis on the different determining variables. The present process-based theoretical study on the practice of relationship marketing will help marketers avoid the potential problems associated with the creation, maintaining, and enhancing of business relationships. Proper practice of such variables helps them build and maintain a win-win relationship that may result in economic performance, customer satisfaction and retention, joint value creation, and competitive advantage.

Much research remains to be done to explore the multifaceted nature of relationship marketing. This framework is a potentially useful starting point for the development of an improved understanding of the aspects of relationship marketing in terms of its creation, maintenance, and enhancement. This study does not attempt to establish the impact of diversified variables on the relationship marketing practice. Thus, future experimental studies can explore this issue and provide evidence for more or less influencing variables that can be of assistance to management in decision making. 


\section{References}

1. Adrian, P. J. (1996). Relationship marketing: a universal paradigm or management fad?. The Learning Organization, 3(3), 18-25.

2. Anderson, J. C., \& Narus, J. A. (1990). A model of distributor firm and manufacturer firm working partnerships. Journal of Marketing, 54(1), 42-58.

3. Baiden, B. K., Price, A. D., \& Dainty, A. R. (2006). The extent of team integration within construction projects. International journal of project management, 24(1), 13-23.

4. Barnes, J. G. (1994). Close to the customer: but is it really a relationship?. Journal of Marketing Management, 10(7), 561-70.

5. Berry, L. (1983). Relationship Marketing. In: L. L. Berry, G. L. Shostack \& G. D. Upah (Eds.), Emerging Perspectives on Service Marketing. Chicago, IL: American Marketing Association.

6. Bolton, R. N. (1998). A dynamic model of the duration of the customer's relationship with a continuous service provider: the role of satisfaction. Marketing Science, 17(11), 45-65.

7. Brettel, M., Strese, S., \& Flatten, T. C. (2012). Improving the performance of business models with relationship marketing efforts - An entrepreneurial perspective. European Management Journal, 30(2), 85-98.

8. Britton, J. E., \& Rose, J. (2004). Thinking about relationship theory. In: D. Peppers \& M. Rogers (eds.), Managing customer relationships: a strategic framework. Hoboken, NJ: Wiley.

9. Brown, J. R., Crosno, J. L., \& Tong, P. Y. (2019). Is the theory of trust and commitment in marketing relationships incomplete?. Industrial Marketing Management, 77, 155-169.

10. Campbell, A. J. (2003). Creating customer knowledge competence: managing customer relationship management programs strategically. Industrial Marketing Management, 32(5), 375-383.

11. Chris, F., \& Graham, H. (2007). Relationship and Marketing Communication. Journal of relationship marketing: financial time's. Prentice-Hall.

12. Clark, T. (1990). International Marketing and National Character: A Review and Proposal for Integrative Theory. Journal of Marketing, 54(4), 66-79.

13. Crone, P. (1989). Pre-Industrial Societies. Cambridge, MA: Basil Blackwell.

14. Crosby, L. A., Evans, K. R., \& Cowles, D. (1990). Relationship Quality in Services Selling: An Interpersonal Influence Perspective. Journal of Marketing, 52(2), 21-34.

15. Cundiff, E. W. (1988). The Evolution of Retailing Institutions across Cultures. In: T. Nevett \& R. A. Fullerton (eds.), Historical Perspectives in Marketing: Essays in Honor of Stanley C. Hollander. Lexington, MA: Lexington Books.

16. Dash, S., Bruning, E., \& Guin, K. K. (2007). Antecedents of Long-Term Buyer-Seller Relationships: A Cross Cultural Integration. Academy of Marketing Science Review, 11(1), 1-29.

17. Dwyer, F. R., Schurr, P. H., \& Oh, S. (1987). Developing buyer-seller relationships. Journal of Marketing, 51(2), 11-27.

18. Eiriz, V., \& Wilson, D. (2006). Research in relationship marketing: antecedents, traditions and integration. European Journal of Marketing, 40(3/4), 275-291.

19. Feltwell, J. (1991). The Story of Silk. New York, NY: St. Martin's Press.

20. Fournier, S., Dobscha, S. \& Mick, D. G. (1998). Preventing the premature death of relationship marketing. Harvard Business Review, 76(1), 42-51.

21. Ganesan, S. (1994). Determinants of long-term orientation in buyer-seller relationships. Journal of Marketing, 58(2), 1-19.

22. Garbarino, E., \& Johnson, M. S. (1999). The different roles of satisfaction, trust, and commitment in customer relationships. Journal of Marketing, 63, 70-87.

23. Gelderblom, O., \& Trivellato, F. (2018). The business history of the preindustrial world: Towards a comparative historical analysis. Business History, 61(2), 225-259. 
24. Geyskens, I., Steenkamp, J. B. E., Scheer, L. K., \& Kumar, N. (1996). The effects of trust and interdependence on relationship commitment: A trans-Atlantic study. International Journal of Research in Marketing, 13(4), 303-317.

25. Gill, M. J., Swann Jr., W. B., \& Silvera, D. H. (1998). On the genesis of confidence. Journal of Peiwnality and Social Psychology, 75(5), 1101-1114.

26. Godson, M. (2010). Relationship Marketing. New York, NY: Oxford University Press.

27. Grönroos, C. (1990). Service Management and Marketing. Managing the Moments of Truth in Service Competition. Lexington, MA: Free Press/Lexington Books.

28. Grönroos, C. (1995). From Marketing Mix to Relationship Marketing: Towards a Paradigm shift in Marketing. Management Decision, 32(2), 4-20.

29. Gundlach, G. T., Achrol, R. S., \& Mentzer, J. T. (1995). The structure of commitment in exchange. Journal of Marketing, 59(1), 78-92.

30. Hakansson, H. (1982). International Marketing and Purchasing of Industrial Goods: An Interaction Approach. Chichester: John Wiley \& Sons.

31. Håkansson, H. (1989). Corporate technological behaviour. Cooperation and networks. London: Routledge.

32. Håkansson, H., \& Snehota, I. (1995). Developing Relationships in Business Networks. $1^{\text {st }}$ ed. London: Routledge.

33. Hallen, L. (1986). A Comparison of Strategic Marketing Approaches. In: P. W. Turnbull \& P. J. Valla (Eds.), Strategies for International Industrial Marketing (pp. 235-249). London: Croom Helm.

34. Hallen, L., \& Sandstorm, M. (1991). Relationship Atmosphere in International Business. In: S. J. Paliwoda (Ed.), New Perspectives on International Marketing. London: Routledge.

35. Hallen, L., Johanson, J., \& Seyed M. N. (1989). Relationships and Exchange in International and Domestic Business. In: L. Hallen \& J. Johanson (Eds.), Networks of Relationships in International Industrial Marketing. Greenwich: JAI Press.

36. Hart, C. W. (1996). Technology is making it feasible to reach that market of one. Make sure that you're the first mover. Marketing Management, 5(2), 10-18.

37. Hoffman, D. L., \& Novak, T.M. (1996). Marketing in Hypermedia Computer Mediated Environments: Conceptual Foundations. Journal of Marketing, 60(3), 50-68.

38. Hofstede, G. (1980). Cultures Consequences: International Differences in Work Related Values. Beverly Hills, CA: Sage Publications.

39. Hofstede, G. (1983). The cultural relativity of organizational practices and theories. Journal of International Business Studies, 14(2), 75-89.

40. Hwang, S., \& Suh, E. (2017). An Empirical Study on the Vendor's Opportunism in the Collaboration between Buyer and Vendor. International Journal of Industrial Distribution \& Business, 8(5), 53-63.

41. Hwang, Y., Seo, C., \& Choi, S. (2013). The Effects of Franchise's Learning Orientation and Relationship Marketing Orientation on the Job Satisfaction. Journal of Distribution Science, 11(6), 51-58.

42. Jobber, D., \& Fahy, J. (2006). Foundations of marketing. New York, NY: McGraw-Hill.

43. Keegan, B. J., Rowley, J., \& Tonge, J. (2017). Marketing agency - client relationships: towards a research agenda. European Journal of Marketing, 51(7/8), 1197-1223.

44. Kelley, H. H., \& Thibaut, J. W. (1978). Interpersonal relations: A theory of interdependence. New York, NY: Wiley.

45. Khalil, O. E. M., \& Harcar, T. D. (1999). Relationship Marketing and Data Quality Management. Advanced Management Journal, 64(2), 26-33.

46. Kingson, E. R., Hirshorn, B. A., \& Cornmarn, J. M. (1986). Ties that Bind: The Interdependence of Generations. Santa Ana, CA: Seven Locks Press. 
47. Korneliussen, T. (2011). Marketing relationships Outside the Marketing Realm. Industrial Marketing and Purchasing.

48. Kotler, P., Armstrong, G., Agnihotri, P. K., \& Haque, E. (2010). Principles of Marketing a South Asian Perspective. $13^{\text {th }}$ ed. Singapore: Pearson Education.

49. Krznaric, D., \& Popovski, G. (2001). Key Account management in International Context. Elanders Novum: Graduate Business Schoool.

50. Li, L. M. (1981). Chinaís Silk Trade: Traditional Industry in the Modern World 1842- 1937. Cambridge, MA: Harvard University Press.

51. Little, R. W. (1970). The marketing channel: who should lead this extra-corporate organization? Journal of Marketing, 34(1), 31-38.

52. Macaulay, S. (1963). Non-contractual relations in business: A preliminary study. American Sociological Review, 28(1), 55-67.

53. Mattsson, L. G. (1995). Relationships and Networks. In: M. J. Baker (Ed.), Companion Encyclopedia of Marketing. London: Routledge.

54. McCammon, B. (1965). The Emergence and Growth of Contractually Integrated Channels in the American Economy. In: P. D. Bennett (Ed.), Economic Growth, Competition, and World Markets (pp. 496-515). Chicago, IL: American Marketing Association.

55. Mishra, A. A. (2016). The role of customer gratitude in relationship marketing: moderation and model validation. Journal of Strategic Marketing, 24(6), 529-549.

56. Moorman, C., Zaltman, G., \& Deshpande, R. (1992). Relationships between providers and users of market research: The dynamics of trust within and between organizations. Journal of Marketing Research, 29(3), 314-328.

57. Morgan, R. M., \& Hunt, S. D. (1994). The commitment-trust theory of relationship marketing. Journal of Marketing, 58(3), 20-38.

58. Mwamula-Lubandi, E. D. (1992). Clan Theory in African Development Studies. New York, NY: University Press of America.

59. Mysen, T., Svensson, G., \& Payan, J. M. (2011). Causes and outcomes of satisfaction in business relationships. Marketing Intelligence \& Planning, 29(2), 123-140.

60. Nelson, R. R., \& Winter, S. G. (1982). An Evolutionary Theory of Economic Change. Cambridge, MA: Belknap Press of the Harvard University Press.

61. Newman, K. L., \& Nollen, S. D. (1996). Culture and congruence: The fit between management practices and national culture. Journal of International Business Studies, 27(4), 753-779.

62. Palmatier, R. W., Jarvis, C. B., Bechkoff, J. R., \& Kardes, F. R. (2009). The role of customer gratitude in relationship marketing. Journal of Marketing, 73(5), 1-18.

63. Palmer, R., Lindgreen, A., \& Vanhamme, J. (2005). Relationship marketing: schools of thought and future research directions. Marketing Intelligence \& Planning, 23(3), 313-330.

64. Patterson, P. G. (1995). The determinants of satisfaction/dissatisfaction for business-to-business, professional services: a conceptual model. Advances in Services Marketing and Management, 2, 1-16.

65. Payne, A., \& Frow, P. (2005). A strategic framework for customer relationship management. Journal of Marketing, 69(4), 167-176.

66. Pedron, C. D., \& Saccol, A. Z. (2009). What Lies behind the Concept of Customer Relationship Management?. Discussing the Essence of CRM through a Phenomenological Approach. Brazilian Administration Review, 6(1), 34-49.

67. Peterson, P. G. (1962). Conventional wisdom and the sixties. Journal of Marketing, 26(2), 63-67.

68. Pillai, K. G., \& Sharma, A. (2003). Mature relationships: Why does relational orientation turn into transaction orientation?. Industrial Marketing Management, 32(8), 643-651. 
69. Raggio, R., Walz, A., Godbole, M. B., \& Garretson Folse, J. A. (2014). Gratitude in relationship marketing: theoretical development and directions for future research. European Journal of Marketing, 48(1/2), 2-24.

70. Robicheaux, R. A., \& El-Ansary, A. I. (1976). A General Model for Understanding Channel Member Behavior. Journal of Retailing, 52, 13-30.

71. Seiders, K., Voss, G. B., Grewal, D., \& Godfrey, A. L. (2005). Do satisfied customers buy more? Examining moderating influences in a retailing context. Journal of Marketing, 69(4), 26-43.

72. Sheth, J. N. (2011). The double helix of marketing: The complementary relationship between marketing history and marketing theory. Marketing Theory, 11(4), 503-505.

73. Sheth, J. N., \& Parvatiyar, A. (1995). The evolution of relationship marketing. International Business Review, 4(4), 402-411.

74. Sheth, J. N., Parvatiyar, A., \& Sinha, M. (2015). The conceptual foundations of relationship marketing: Review and synthesis. Journal of Economic Sociology - Ekonomicheskaya sotsiologiya, 16(2), 119-149.

75. Smith, K. G., Carroll, S. J., \& Ashford, S. J. (1995). Intra-and interorganizational cooperation: Toward a research agenda. Academy of Management Journal, 38(1), 7-23.

76. Storbacka, K., Strandvik, T., \& Grönroos, C. (1994). Managing customer relationships for profit: the dynamics of relationship quality. International Journal of Service Industry Management, 5(5), 21-38.

77. Todeva, E. (2005). Complexity of Business Network Relationships. Proceedings of the $1^{\text {st }}$ First UK SNA Conference 'Social Network Analysis: Advances \& Empirical Applications,' July 16-17, 2005, University of Oxford.

78. Tse, D. K., Lee, K., Vertinsky, I., \& Wehrung, D. A. (1988). Does culture matter? A cross-cultural study of executives' choice, decisiveness, and risk adjustment in international marketing. Journal of Marketing, 52(4), 81-95.

79. Walter, A., Ritter, T., \& Gemünden, H. G. (2001). Value Creation in Buyer- Seller Relationships: Theoretical Considerations and Empirical Results from a Supplier's Perspective. Industrial Marketing Management, 30(4), 365-377

80. Wang, C. L., Shi, Y., \& Barnes, B. R. (2015). The role of satisfaction, trust and contractual obligation on long-term orientation. Journal of Business Research, 68(3), 473-479.

81. Wang, Y., Po Lo, H., Chi, R., \& Yang, Y. (2004). An integrated framework for customer value and customer-relationship-management performance: a customer-based perspective from China. Managing Service Quality: An International Journal, 14(2/3), 169-182.

82. Wendelin, R. (2011). Bond audit, a method for evaluating business relationships. Journal of Business and Industrial Marketing, 26(3), 211-217.

83. Wilson, D. T. (1995). An integrated model of buyer-seller relationships. Journal of the Academy of Marketing Science, 23(4), 335-345.

84. Wilson, D. T., \& Mummalaneni, V. (1986). Bonding and commitment in supplier relationship: a preliminary conceptualization. Industrial Marketing and Purchasing, 1(3), 44-58.

85. Winer, R. S. (2001). A framework for customer relationship management. California Management Review, 43(4), 89-105. 